\title{
Populations of Botrytis cinerea and Penicillium spp. on Pear Fruit, and in Orchards and Packinghouses, and Their Relationship to Postharvest Decay
}

\author{
Cheryl L. Lennox, Plant Protection Research Institute, Private Bag X 5017, Stellenbosch, South Africa; and \\ Robert A. Spotts and Louis A. Cervantes, Oregon State University Mid-Columbia Agricultural Research and
} Extension Center, Hood River 97031

\begin{abstract}
Lennox, C. L., Spotts, R. A., and Cervantes, L. A. 2003. Populations of Botrytis cinerea and Penicillium spp. on pear fruit, and in orchards and packinghouses, and their relationship to postharvest decay. Plant Dis. 87:639-644.

The aims of this study were to examine the sources and population sizes of Botrytis cinerea and Penicillium spp. in 'd'Anjou' pear orchards, packinghouses, and storage, and to determine the relationship between population sizes and postharvest decay. Densities of $B$. cinerea ranged from nondetectable to $4.0 \mathrm{CFU} / \mathrm{cm}^{2}$ on fruit, nondetectable to $3.1 \mathrm{CFU} / \mathrm{liter}$ in orchard air, and nondetectable to $1,167 \mathrm{CFU} / \mathrm{g}$ in orchard litter. The majority of packinghouse air and orchard soil samples collected yielded no B. cinerea inoculum. Densities of Penicillium spp. ranged from nondetectable to $2.7 \mathrm{CFU} / \mathrm{cm}^{2}$ on pear fruit, nondetectable to $3.13 \mathrm{CFU} /$ liter in orchard air, nondetectable to $11.8 \mathrm{CFU} /$ liter in packingline air, nondetectable to $3.9 \mathrm{CFU} /$ liter in cold-storage air, 38 to $431 \mathrm{CFU} / \mathrm{g}$ in orchard soil, and 131 to $1,128 \mathrm{CFU} / \mathrm{g}$ in orchard litter. The mean incidence of gray mold in stored d'Anjou pear fruit ranged from 0.7 to $10.7 \%$. Incidence of blue mold ranged from 0 to $16.5 \%$. Significant positive correlations were observed between decay and fruit surface populations of B. cinerea and Penicillium spp. In conclusion, inoculum levels of these important postharvest pathogens in orchard and packinghouse air, and orchard soil and litter, cannot be used as indicators of postharvest decay; whereas the inoculum level on fruit surfaces may be a useful predictor of decay.
\end{abstract}

Botrytis and Penicillium spp. are among the most commonly found plant pathogens and saprophytes $(2,10)$, with Botrytis cinerea Pers.:Fr. and Penicillium expansum Link ex Thom. being responsible for a significant portion of postharvest losses incurred by the pear-packing industry of the Pacific Northwest $(13,15,18,21)$. Levels of gray mold caused by $B$. cinerea and blue mold caused by $P$. expansum in stored 'd'Anjou' pears varies with year, grower, and often fruit lot. The availability of reliable models for predicting decay caused by these pathogens would be of great value to the industry. Fruit predicted as having a high incidence of decay could be sold first, whereas fruit predicted to have a low incidence of decay could be safely stored for longer periods.

Propagules of these decay fungi found in soil, plant litter, air $(8,21)$, and packing-

Corresponding author: C. L. Lennox

E-mail: vredc1@plant3.agric.za

Use of trade names in this article does not imply endorsement by Oregon State University of the products named or criticism of similar products not mentioned.

Oregon Agricultural Experiment Station technical paper 11868 .

Accepted for publication 7 December 2002.

Publication no. D-2003-0324-04R

(C) 2003 The American Phytopathological Society house dump tank water $(3,4,5,18,21)$ are potential sources of inoculum for postharvest decay. It is generally assumed that the initial inoculum of these decay-causing fungi originates in the orchard (8) and is dispersed as dry or wet conidia that could land on dry fruit, or fruit wet with dew or rain. Spotts and Cervantes (23), using a settling tower (17), inoculated dry and wet d'Anjou pear fruit with dry conidia of $B$. cinerea and $P$. expansum. They found a highly significant linear relationship between decay incidence and conidial concentration. Although inoculum densities of these two pathogens have been quantified in the packinghouse environment $(18,21)$, there is little information available on inoculum levels in the pear orchard environment, including air, soil, and litter, and their relationship to decay.

The objectives of this study were to determine the density of $B$. cinerea and Penicillium spp. populations in both the pear orchard and packinghouse environments, to examine the incidence of postharvest decay caused by of $B$. cinerea and Penicillium spp. on d'Anjou pears, and to determine the relationships between the various sources of inoculum and incidence of postharvest decay.

\section{MATERIALS AND METHODS}

Populations on the fruit surface. From 1994 to 1998, d'Anjou pear fruit were collected about 1 week before harvest in several orchards in the Mid-Columbia region of Oregon and Washington. In 1999, fruit were collected 24 days before harvest. The number of fruit sampled per orchard was 6 (1996 and 1997), 10 (1998), 12 (1994 and 1995), or 50 (1999). Fruit were handled carefully by the pedicel to avoid disturbing the surface. Each fruit was weighed, then immersed in sterile distilled water containing $0.1 \%$ Tween 80 . Fruit were shaken on a rotary shaker at $150 \mathrm{rpm}$ for $5 \mathrm{~min}$ (10 $\mathrm{min}$ in 1999), then sonicated (L \& R model T-14; L \& R Manufacturing Co., Kearny, NJ) for $5 \mathrm{~min}(10 \mathrm{~min}$ in 1999). In 1999, five fruit per tree were collected from 10 replicate trees, and all fruit from each tree were successively immersed in the same wash water. A 0.20or $0.40-\mathrm{ml}$ aliquot of the wash water was placed on duplicate petri dishes of Botrytis-selective Kerssies medium (11) (1994 to 1997) or acidified potato dextrose agar (APDA) (1998 and 1999). The decision to change to APDA was made in 1998 in order to include Penicillium spp. in our observations. Plates were incubated at $22^{\circ} \mathrm{C}$ for 1 (APDA) or 2 (Kerssies) weeks, after which time all fungal colonies were examined to determine their identity. Surface area of each fruit was estimated from a regression equation (6) with fresh weight as the independent variable. Population densities were calculated from plate counts, dilution factors, and fruit area, and expressed as CFU per unit surface area of fruit.

Airborne population density. Air was sampled 1 week before harvest in 1996 to 1998 and 24 days before harvest in 1999 in several orchards in the Mid-Columbia region of Oregon and Washington. A portable air sampler for agar plates (Burkard Manufacturing Co., Ltd., Hertfordshire, UK) was used to sample the air. Orchard air was sampled between 8:00 and 10:00 A.M. during windless periods. Air samples from the packingline area of commercial packinghouses were collected during the 1996 to 2000 packing seasons while the lines were operational. In orchards and packingline areas, 10 liters of air (20 liters in orchards in 1999) were impinged onto a petri dish containing $27 \mathrm{ml}$ of APDA. In cold-storage rooms, 20 liters of air were sampled. Three (1996 to 1998) and five (1999) replicate samples were collected in each orchard and three samples in each packinghouse. Plates were incubated at 
$22^{\circ} \mathrm{C}$ and examined under a stereomicroscope at $\times 12$ after an incubation period of 2 to 4 days to determine colony identities and numbers.

Populations in orchard soil and litter. Loose surface litter (consisting of detritus, and excluding living plant material) and soil in the top $5 \mathrm{~cm}$ were collected 1 week before harvest in 1996 to 1998 and 24 days before harvest in 1999 from the north, south, east, and west sides of the drip line of three trees in each orchard. Litter samples were kept separate from soil samples. The 12 soil or litter samples from each orchard were pooled and mixed. A 100-g subsample was removed and blended for $30 \mathrm{~s}$ with $200 \mathrm{ml}$ of sterile distilled water. After $2 \mathrm{~min}$ of settling, $100 \mu \mathrm{l}$ of supernatant was spread on each of three petri dishes containing Kerssies medium (1996 and 1997) or APDA (1998 and 1999). Dishes were kept at $22^{\circ} \mathrm{C}$ and all fungal colonies counted after 5 to 7 days for APDA and 14 days for Kerssies. In 1999, soil and litter samples were collected from around each of 10 trees and processed separately.

Decay of fruit in cold storage. Fruit were harvested about 1 week before commercial harvest. In 1996 and 1997, harvested fruit from each orchard were placed into 10 wood boxes, each containing about $18 \mathrm{~kg}$ of fruit. In 1998, 20 boxes of fruit were harvested from each orchard. Boxes were lined with perforated polyethylene bags, and fruit were stored in air at $-1^{\circ} \mathrm{C}$. Fruit were evaluated for incidence of blue and gray mold after 3, 6, and 8 months.

Table 1. Populations of Botrytis cinerea and Penicillium spp. on the surface of 'd'Anjou' pear fruit 7 or 24 days before commercial harvest $\mathrm{t}^{\mathrm{a}}$

\begin{tabular}{|c|c|c|c|c|c|c|}
\hline \multirow[b]{3}{*}{ Orchard } & \multicolumn{6}{|c|}{ Population $\left(\mathrm{CFU} / \mathrm{cm}^{2}\right)^{b}$} \\
\hline & \multicolumn{4}{|c|}{ Botrytis cinerea } & \multicolumn{2}{|c|}{ Penicillium spp. } \\
\hline & 1996 & 1997 & 1998 & 1999 & 1998 & 1999 \\
\hline 1 & $0.2 \pm 0.2$ & $\ldots$ & $0.0 \pm 0.0$ & & $2.7 \pm 1.5$ & \\
\hline 2 & $0.0 \pm 0.0$ & $0.2 \pm 0.2$ & $0.2 \pm 0.2$ & $1.3 \pm 0.4$ & $0.0 \pm 0.0$ & $0.9 \pm 0.7$ \\
\hline 3 & $0.8 \pm 0.4$ & $0.0 \pm 0.0$ & $0.0 \pm 0.0$ & $\ldots$ & $0.3 \pm 0.2$ & $\ldots$ \\
\hline 4 & $0.8 \pm 0.6$ & $0.2 \pm 0.2$ & $0.0 \pm 0.0$ & $\ldots$ & $0.2 \pm 0.2$ & $\ldots$ \\
\hline 5 & $0.4 \pm 0.3$ & $0.2 \pm 0.2$ & $0.0 \pm 0.0$ & $\ldots$ & $0.0 \pm 0.0$ & $\ldots$ \\
\hline 6 & $1.4 \pm 0.9$ & $1.0 \pm 0.5$ & $0.0 \pm 0.0$ & $\ldots$ & $0.0 \pm 0.0$ & $\ldots$ \\
\hline 7 & $0.3 \pm 0.3$ & $0.6 \pm 0.4$ & $0.0 \pm 0.0$ & $\ldots$ & $0.0 \pm 0.0$ & $\ldots$ \\
\hline 8 & $0.5 \pm 0.5$ & $0.7 \pm 0.3$ & $\ldots$ & $\ldots$ & $\ldots$ & $\ldots$ \\
\hline 9 & $0.0 \pm 0.0$ & $0.6 \pm 0.4$ & $\ldots$ & $\ldots$ & $\ldots$ & $\ldots$ \\
\hline 10 & $0.3 \pm 0.3$ & $0.9 \pm 0.5$ & $\ldots$ & $\cdots$ & $\ldots$ & $\ldots$ \\
\hline 11 & $0.3 \pm 0.3$ & $0.0 \pm 0.0$ & $\ldots$ & $\ldots$ & $\ldots$ & $\ldots$ \\
\hline 12 & $0.0 \pm 0.0$ & $0.4 \pm 0.2$ & $\ldots$ & $\cdots$ & $\cdots$ & $\ldots$ \\
\hline 13 & $0.2 \pm 0.2$ & $0.0 \pm 0.0$ & $\ldots$ & $\ldots$ & $\ldots$ & $\ldots$ \\
\hline 14 & $0.7 \pm 0.7$ & $\ldots$ & $\ldots$ & $\ldots$ & $\ldots$ & $\cdots$ \\
\hline 15 & $0.6 \pm 0.4$ & $\ldots$ & $\cdots$ & $\ldots$ & $\ldots$ & $\ldots$ \\
\hline 16 & $0.2 \pm 0.2$ & $0.0 \pm 0.0$ & $\ldots$ & $\ldots$ & $\ldots$ & $\ldots$ \\
\hline
\end{tabular}

${ }^{a}$ Spores removed from fruit by combination of rotary shaking and sonication, then plated on acidified potato dextrose agar or Kerssies medium.

${ }^{\mathrm{b}}$ Mean \pm standard error of the mean of 6 to 50 fruit. Fruit sampled 1 week before commercial harvest in 1996 to 1998, and 24 days before commercial harvest in 1999.
After each evaluation, visibly decayed fruit were removed to prevent secondary spread. After the 8-month evaluation, fruit were ripened at $20^{\circ} \mathrm{C}$ for 7 days and evaluated again. Decay in all evaluations was summed and the total percent of decayed fruit was calculated.

Data analysis. The relationship between population levels of $B$. cinerea and Penicillium spp. and decay in storage caused by these two pathogens were examined. Correlation coefficients were determined based on simple linear relationships between fungal populations on fruit surfaces, in orchard and packinghouse air, and in orchard soil and litter, and between fungal populations and incidence of postharvest decay after storage.

\section{RESULTS}

Populations on the fruit surface. The average fruit surface area was $150 \mathrm{~cm}^{2}$. Considerable variability in propagule density was observed on surfaces of harvested fruit. Density of B. cinerea was $4.0 \pm 1.1$ and $0.6 \pm 0.3 \mathrm{CFU} / \mathrm{cm}^{2}$ in 1994 and 1995, respectively. Density of $B$. cinerea ranged from nondetectable to $1.4 \mathrm{CFU} / \mathrm{cm}^{2}$ on fruit collected prior to commercial harvests in 1996 through 1999 (Table 1). Population density of Penicillium spp. on the surface of pear fruit prior to commercial harvests of 1998 and 1999 ranged from nondetectable to $2.7 \mathrm{CFU} / \mathrm{cm}^{2}$ (Table 1).

Airborne population density. Propagule densities in the air of d'Anjou pear orchards prior to commercial harvest in 1996 through 1999 ranged from nondetectable to $3.1 \mathrm{CFU} /$ liter for $B$. cinerea, and from nondetectable to $3.13 \mathrm{CFU} / \mathrm{liter}$ for Penicillium spp. (Table 2). Population densities of Penicillium spp. in air collected near the packingline of commercial packinghouses during 1996 to 2000 ranged from 0.1 to $11.8 \mathrm{CFU} /$ liter (Table 3 ). The

Table 2. Populations of Botrytis cinerea and Penicillium spp. in the air of 'd'Anjou' pear orchards 7 or 24 days before commercial harvest ${ }^{\mathrm{a}}$

\begin{tabular}{|c|c|c|c|c|c|c|c|}
\hline \multirow[b]{3}{*}{ Orchard } & \multicolumn{7}{|c|}{ Population (CFU/liter of air) ${ }^{b}$} \\
\hline & \multicolumn{4}{|c|}{ Botrytis cinerea } & \multicolumn{3}{|c|}{ Penicillium spp. } \\
\hline & 1996 & 1997 & 1998 & 1999 & 1996 & 1998 & 1999 \\
\hline 1 & $0.00 \pm 0.00$ & & $\ldots$ & . & $0.00 \pm 0.00$ & $\ldots$ & $\ldots$ \\
\hline 2 & $0.23 \pm 0.15$ & $3.10 \pm 1.43$ & $0.00 \pm 0.00$ & $0.12 \pm 0.03$ & $0.07 \pm 0.07$ & $0.57 \pm 0.18$ & $0.10 \pm 0.03$ \\
\hline 3 & $0.17 \pm 0.09$ & $0.03 \pm 0.03$ & $0.07 \pm 0.07$ & $\ldots$ & $0.13 \pm 0.03$ & $1.13 \pm 0.41$ & $\ldots$ \\
\hline 4 & $0.37 \pm 0.07$ & $0.00 \pm 0.00$ & $0.03 \pm 0.03$ & $\ldots$ & $0.10 \pm 0.06$ & $0.43 \pm 0.23$ & $\ldots$ \\
\hline 5 & $0.23 \pm 0.12$ & $0.33 \pm 0.19$ & $0.07 \pm 0.07$ & $\ldots$ & $0.37 \pm 0.09$ & $0.80 \pm 0.35$ & $\ldots$ \\
\hline 6 & $0.10 \pm 0.06$ & $0.00 \pm 0.00$ & $0.10 \pm 0.10$ & $\ldots$ & $0.33 \pm 0.07$ & $3.13 \pm 0.45$ & $\ldots$ \\
\hline 7 & $0.03 \pm 0.03$ & $0.10 \pm 0.06$ & $0.10 \pm 0.10$ & $\ldots$ & $0.13 \pm 0.03$ & $0.80 \pm 0.44$ & $\ldots$ \\
\hline 8 & $0.33 \pm 0.15$ & $0.20 \pm 0.20$ & $\ldots$ & $\ldots$ & $1.37 \pm 0.03$ & $\ldots$ & $\ldots$ \\
\hline 9 & $0.07 \pm 0.07$ & $0.07 \pm 0.03$ & $\ldots$ & $\ldots$ & $0.00 \pm 0.00$ & $\ldots$ & $\ldots$ \\
\hline 10 & $0.07 \pm 0.07$ & $0.00 \pm 0.00$ & $\ldots$ & $\ldots$ & $0.00 \pm 0.00$ & $\ldots$ & $\ldots$ \\
\hline 11 & $0.17 \pm 0.09$ & $0.00 \pm 0.00$ & $\ldots$ & $\ldots$ & $0.03 \pm 0.03$ & $\ldots$ & $\ldots$ \\
\hline 12 & $0.47 \pm 0.19$ & $1.47 \pm 1.13$ & $\ldots$ & $\ldots$ & $0.00 \pm 0.00$ & $\ldots$ & $\ldots$ \\
\hline 13 & $0.00 \pm 0.00$ & $0.00 \pm 0.00$ & $\ldots$ & $\ldots$ & $0.03 \pm 0.03$ & $\ldots$ & $\ldots$ \\
\hline 14 & $0.00 \pm 0.00$ & $\ldots$ & $\ldots$ & $\ldots$ & $0.00 \pm 0.00$ & $\ldots$ & $\ldots$ \\
\hline 15 & $0.33 \pm 0.09$ & $\ldots$ & $\ldots$ & $\ldots$ & $0.03 \pm 0.03$ & $\ldots$ & $\ldots$ \\
\hline 16 & $0.33 \pm 0.07$ & $0.17 \pm 0.09$ & $\ldots$ & $\ldots$ & $0.10 \pm 0.06$ & $\ldots$ & $\ldots$ \\
\hline
\end{tabular}

${ }^{a}$ Ten liters impinged onto each acidified potato dextrose agar plate (20 liters in 1999) with a Burkard portable air sampler for agar plates.

b Mean \pm standard error of the mean of three (1996 to 1998) or five (1999) samples. Air sampled 1 week before commercial harvest, 1996 to 1998 , and 24 days before commercial harvest in 1999. 
highest levels of Penicillium spp. were found in packingline air samples collected after January (Table 3). Density of Penicillium spp. in air samples collected from the cold-storage facilities ranged from nondetectable to $3.9 \mathrm{CFU} / \mathrm{liter}$, and the increase in population density of this pathogen that was observed in packingline

Table 3. Populations of Penicillium spp. in packinghouse air

\begin{tabular}{|c|c|c|c|}
\hline \multirow[b]{2}{*}{ Date } & \multirow[b]{2}{*}{ House } & \multicolumn{2}{|c|}{ Population (CFU/liter)a } \\
\hline & & Packingline & Cold storage \\
\hline 20 December 1996 & 1 & $0.7 \pm 0.0$ & $0.0 \pm 0.0$ \\
\hline 20 December 1996 & 2 & $0.8 \pm 0.1$ & $0.1 \pm 0.1$ \\
\hline 20 December 1996 & 3 & $3.4 \pm 0.3$ & \\
\hline 3 January 1997 & 4 & $0.8 \pm 0.0$ & $0.2 \pm 0.1$ \\
\hline 28 January 1997 & 4 & $5.1 \pm 0.1$ & $1.9 \pm 0.1$ \\
\hline 1 February 1997 & 1 & $0.3 \pm 0.1$ & $0.1 \pm 0.1$ \\
\hline 1 February 1997 & 2 & $1.1 \pm 0.3$ & $0.0 \pm 0.0$ \\
\hline 1 February 1997 & 4 & $8.1 \pm 0.5$ & $0.8 \pm 0.2$ \\
\hline 14 February 1997 & 4 & $7.6 \pm 0.1$ & $1.4 \pm 0.3$ \\
\hline 24 February 1997 & 4 & $9.7 \pm 0.3$ & $0.5 \pm 0.2$ \\
\hline 29 January 1998 & 2 & $5.9 \pm 1.3$ & $0.8 \pm 0.1$ \\
\hline 18 February 1998 & 4 & $8.0 \pm 2.0$ & $0.1 \pm 0.0$ \\
\hline 3 March 1998 & 1 & $3.4 \pm 0.4$ & $0.2 \pm 0.1$ \\
\hline 3 March 1998 & 3 & $5.8 \pm 1.5$ & $0.1 \pm 0.1$ \\
\hline 21 April 1998 & 4 & $5.1 \pm 0.3$ & $0.6 \pm 0.1$ \\
\hline \multirow[t]{4}{*}{22 January 1999} & 1 & $0.8 \pm 0.2$ & $1.8 \pm 1.1$ \\
\hline & 2 & $0.4 \pm 0.3$ & $1.8 \pm 0.2$ \\
\hline & 3 & $0.2 \pm 0.1$ & $0.3 \pm 0.1$ \\
\hline & 4 & $1.6 \pm 0.2$ & $3.1 \pm 0.9$ \\
\hline 27 January 1999 & 4 & $4.6 \pm 0.4$ & $0.8 \pm 0.1$ \\
\hline \multirow[t]{3}{*}{28 January 1999} & 1 & $0.1 \pm 0.0$ & $0.0 \pm 0.0$ \\
\hline & 2 & $0.2 \pm 0.1$ & $0.0 \pm 0.0$ \\
\hline & 3 & $0.2 \pm 0.2$ & $0.2 \pm 0.1$ \\
\hline 1 March 1999 & 4 & $6.2 \pm 0.2$ & $3.4 \pm 0.8$ \\
\hline \multirow[t]{2}{*}{7 March 1999} & 1 & $0.2 \pm 0.1$ & $0.4 \pm 0.2$ \\
\hline & 3 & $0.1 \pm 0.1$ & $0.3 \pm 0.2$ \\
\hline 16 March 1999 & 4 & $11.8 \pm 0.6$ & $2.2 \pm 0.1$ \\
\hline \multirow[t]{3}{*}{18 March 1999} & 1 & $0.3 \pm 0.1$ & $0.1 \pm 0.1$ \\
\hline & 2 & $2.3 \pm 0.6$ & $0.9 \pm 0.2$ \\
\hline & 3 & $1.4 \pm 0.6$ & $0.4 \pm 0.3$ \\
\hline 22 March 1999 & 4 & $11.3 \pm 1.9$ & $3.9 \pm 0.5$ \\
\hline 12 January 2000 & 4 & $1.6 \pm 0.7$ & $0.3 \pm 0.1$ \\
\hline \multirow{3}{*}{13 January 2000} & 1 & $0.5 \pm 0.1$ & $0.1 \pm 0.0$ \\
\hline & 2 & $2.1 \pm 0.2$ & $0.2 \pm 0.1$ \\
\hline & 3 & & $0.0 \pm 0.0$ \\
\hline \multirow{3}{*}{26 January 2000} & 1 & $0.3 \pm 0.1$ & $0.0 \pm 0.0$ \\
\hline & 2 & $0.6 \pm 0.1$ & $0.0 \pm 0.0$ \\
\hline & 3 & -0 & $0.0 \pm 0.0$ \\
\hline 1 February 2000 & 4 & $0.2 \pm 0.1$ & $0.1 \pm 0.0$ \\
\hline \multirow[t]{4}{*}{9 February 2000} & 1 & $7.9 \pm 0.3$ & $0.1 \pm 0.0$ \\
\hline & 2 & $2.0 \pm 0.3$ & $0.2 \pm 0.1$ \\
\hline & 3 & $2.0-0.0$ & $0.0 \pm 0.0$ \\
\hline & 4 & $6.5 \pm 1.9$ & $0.6 \pm 0.4$ \\
\hline
\end{tabular}

a Mean \pm standard error of the mean of three samples.

air samples after January was not observed in samples from cold-storage facilities (Table 3). B. cinerea rarely was found in air in the packinghouse or cold storage.

Populations in orchard soil and litter. The majority of soil samples collected in commercial d'Anjou pear orchards before harvest yielded no $B$. cinerea although, in some orchards, populations ranged from 26 to $125 \mathrm{CFU} / \mathrm{g}$ of soil (Table 4). Population density of $B$. cinerea in litter samples collected in commercial d'Anjou pear orchards before harvest ranged from nondetectable to $1,167 \mathrm{CFU} / \mathrm{g}$ (Table 4). Penicillium spp. were found in all soil and litter samples collected in commercial d'Anjou pear orchards in 1998 and 1999. Mean inoculum density ranged from 38 to 431 CFU/g of soil and 131 to $1,128 \mathrm{CFU} / \mathrm{g}$ of litter (Table 4). Densities of Penicillium spp. in the soil were consistently lower that those in the litter (Table 4).

Decay of fruit in cold storage. The mean incidence of gray mold caused by $B$. cinerea in stored d'Anjou pear fruit ranged from 1.9 to $10.7 \%$ in $1996,0.7$ to $6.6 \%$ in 1997 , and 0.9 to $10.1 \%$ in 1998 (Table 5). Incidence of blue mold caused by $P$. expansum in stored d'Anjou pear fruit from commercial orchards ranged from 0 to $8.2 \%$ in $1996,0.5$ to $16.5 \%$ in 1997 , and 0 to $0.5 \%$ in 1998 (Table 5). Limited sporulation occurred on decayed fruit, and fruit were handled carefully to limit exposure of healthy fruit to additional inoculum. In this study, we cannot discount the possibility that fruit monitored for decay might have been exposed to additional inoculum during decay monitoring.

Relationships between population levels and postharvest decay. Significant positive correlations $(P<0.05)$ for $B$. cinerea were observed between decay and fruit surface populations in 1996 and 1998, but not in 1997 (Table 6). Many of the soil samples taken in the pear orchards contained no propagules of $B$. cinerea; consequently, we could not determine the rela-

Table 4. Populations of Botrytis cinerea and Penicillium spp. in soil and litter of 'd'Anjou' pear orchards 7 or 24 days before commercial harvest

\begin{tabular}{|c|c|c|c|c|c|c|c|c|c|c|c|c|}
\hline \multirow[b]{4}{*}{ Orchard } & \multicolumn{12}{|c|}{ Population (CFU/g of dry soil or litter) ${ }^{\mathrm{a}}$} \\
\hline & \multicolumn{8}{|c|}{ Botrytis cinerea } & \multicolumn{4}{|c|}{ Penicillium spp. } \\
\hline & \multicolumn{2}{|r|}{1996} & \multicolumn{2}{|r|}{1997} & \multicolumn{2}{|c|}{1998} & \multicolumn{2}{|c|}{1999} & \multicolumn{2}{|c|}{1998} & \multicolumn{2}{|c|}{1999} \\
\hline & Soil & Litter & Soil & Litter & Soil & Litter & Soil & Litter & Soil & Litter & Soil & Litter \\
\hline 1 & $0 \pm 0$ & $172 \pm 172$ & & & $0 \pm 0$ & $16 \pm 16$ & & & $38 \pm 38$ & $131 \pm 71$ & & \\
\hline 2 & $\ldots$ & & $0 \pm 0$ & $0 \pm 0$ & $0 \pm 0$ & $16 \pm 16$ & $73 \pm 12$ & $253 \pm 14$ & $90 \pm 26$ & $371 \pm 280$ & $431 \pm 117$ & $584 \pm 110$ \\
\hline 3 & $0 \pm 0$ & $0 \pm 0$ & $56 \pm 47$ & $214 \pm 34$ & $0 \pm 0$ & $16 \pm 16$ & $\ldots$ & $\ldots$ & $353 \pm 185$ & $726 \pm 462$ & $\ldots$ & $\ldots$ \\
\hline 4 & $0 \pm 0$ & $0 \pm 0$ & $0 \pm 0$ & $0 \pm 0$ & $0 \pm 0$ & $32 \pm 32$ & $\cdots$ & $\cdots$ & $56 \pm 56$ & $1,128 \pm 206$ & $\ldots$ & $\cdots$ \\
\hline 5 & $\ldots$ & $\ldots$ & $0 \pm 0$ & $0 \pm 0$ & $0 \pm 0$ & $32 \pm 32$ & $\ldots$ & $\ldots$ & $217 \pm 182$ & $1,079 \pm 304$ & $\ldots$ & $\ldots$ \\
\hline 6 & $0 \pm 0$ & $0 \pm 0$ & $0 \pm 0$ & $0 \pm 0$ & $0 \pm 0$ & $47 \pm 47$ & $\ldots$ & $\ldots$ & $64 \pm 64$ & $483 \pm 284$ & $\ldots$ & $\ldots$ \\
\hline 7 & $0 \pm 0$ & $181 \pm 181$ & $0 \pm 0$ & $111 \pm 111$ & $0 \pm 0$ & $50 \pm 29$ & $\ldots$ & $\ldots$ & $125 \pm 66$ & $712 \pm 276$ & $\ldots$ & $\ldots$ \\
\hline 8 & $0 \pm 0$ & $0 \pm 0$ & $26 \pm 26$ & $183 \pm 59$ & $\ldots$ & $\ldots$ & $\ldots$ & $\ldots$ & $\ldots$ & $\ldots$ & $\ldots$ & $\ldots$ \\
\hline 9 & $0 \pm 0$ & $0 \pm 0$ & $0 \pm 0$ & $0 \pm 0$ & $\ldots$ & $\ldots$ & $\ldots$ & $\ldots$ & $\ldots$ & $\ldots$ & $\ldots$ & $\ldots$ \\
\hline 10 & $0 \pm 0$ & $0 \pm 0$ & $0 \pm 0$ & $691 \pm 137$ & $\ldots$ & $\ldots$ & $\ldots$ & $\ldots$ & $\ldots$ & $\ldots$ & $\ldots$ & $\ldots$ \\
\hline 11 & $0 \pm 0$ & $0 \pm 0$ & $6 \pm 6$ & $1,167 \pm 42$ & $\ldots$ & $\ldots$ & $\ldots$ & $\ldots$ & $\ldots$ & $\ldots$ & $\ldots$ & $\ldots$ \\
\hline 12 & $0 \pm 0$ & $0 \pm 0$ & $0 \pm 0$ & $180 \pm 32$ & $\ldots$ & $\ldots$ & $\ldots$ & $\ldots$ & $\ldots$ & $\ldots$ & $\ldots$ & $\ldots$ \\
\hline 13 & $0 \pm 0$ & $0 \pm 0$ & $0 \pm 0$ & $257 \pm 159$ & $\ldots$ & $\ldots$ & $\ldots$ & $\ldots$ & $\ldots$ & $\ldots$ & $\ldots$ & $\ldots$ \\
\hline 16 & $0 \pm 0$ & $0 \pm 0$ & $125 \pm 45$ & $468 \pm 91$ & $\ldots$ & $\ldots$ & $\ldots$ & $\ldots$ & $\ldots$ & $\ldots$ & $\ldots$ & $\ldots$ \\
\hline
\end{tabular}

\footnotetext{
a Mean \pm standard error of the mean. Soil and litter sampled 1 week before commercial harvest in 1996 to 1998 and 24 days before commercial harvest in 1999.
} 
tionship between soil populations and decay caused by this pathogen. The positive correlation between decay caused by $P$. expansum and the population of Penicillium spp. detected on fruit surfaces was significant $(P=0.01)$ in 1998 (Table 6).

\section{DISCUSSION}

The annual and locational variability in postharvest decay levels makes planning of storage and marketing of d'Anjou pear fruit difficult. Currently, levels of postharvest decay caused by $B$. cinerea and $P$. expansum cannot be predicted because no reliable prediction model exists. In this study, we investigated whether inoculum source and size could be used to predict levels of decay in storage. We were not able to distinguish between species of Penicillium collected from the various sources of inoculum and, consequently, we have reported the results for Penicillium spp.

Considerable variability in propagule densities on fruit surfaces was observed in fruit collected before commercial harvest. It is assumed that weather (rain and wind) and orchard management activities cause dispersal of conidia from ground litter, leaves, and bark and deposition onto the

Table 5. Incidence of gray and blue mold in ' $\mathrm{d}$ 'Anjou' pear fruit stored for 8 months at $-1^{\circ} \mathrm{C}$ followed by a ripening period of 7 days at $20^{\circ} \mathrm{C}$

\begin{tabular}{|c|c|c|c|c|c|c|}
\hline \multirow[b]{3}{*}{ Orchard } & \multicolumn{6}{|c|}{ Decay incidence $(\%)^{\mathrm{a}}$} \\
\hline & \multicolumn{3}{|c|}{ Gray mold } & \multicolumn{3}{|c|}{ Blue mold } \\
\hline & 1996 & 1997 & 1998 & 1996 & 1997 & 1998 \\
\hline 1 & $1.9 \pm 0.6$ & & & $0.3 \pm 0.1$ & $\cdots$ & \\
\hline 2 & $8.0 \pm 1.1$ & $5.5 \pm 1.0$ & $10.1 \pm 1.4$ & $0.0 \pm 0.0$ & $1.6 \pm 0.5$ & $0.0 \pm 0.0$ \\
\hline 3 & $4.1 \pm 1.1$ & $4.6 \pm 1.3$ & $1.8 \pm 0.4$ & $2.1 \pm 0.5$ & $3.2 \pm 0.7$ & $0.4 \pm 0.2$ \\
\hline 4 & $7.9 \pm 1.4$ & $3.3 \pm 0.8$ & $2.1 \pm 0.4$ & $2.6 \pm 0.7$ & $5.0 \pm 1.9$ & $0.5 \pm 0.2$ \\
\hline 5 & $6.8 \pm 1.8$ & $6.6 \pm 1.3$ & $0.9 \pm 0.2$ & $0.2 \pm 0.2$ & $3.3 \pm 1.6$ & $0.1 \pm 0.1$ \\
\hline 6 & $10.7 \pm 1.6$ & $3.1 \pm 0.8$ & $3.1 \pm 0.4$ & $0.1 \pm 0.1$ & $2.3 \pm 1.1$ & $0.1 \pm 0.1$ \\
\hline 7 & $7.2 \pm 1.9$ & $3.5 \pm 0.6$ & $7.2 \pm 0.7$ & $0.3 \pm 0.2$ & $0.5 \pm 0.3$ & $0.0 \pm 0.0$ \\
\hline 8 & $3.2 \pm 0.7$ & $1.3 \pm 0.6$ & $\ldots$ & $1.4 \pm 0.3$ & $7.0 \pm 1.9$ & $\ldots$ \\
\hline 9 & $3.9 \pm 1.2$ & $2.5 \pm 0.6$ & $\ldots$ & $1.4 \pm 0.6$ & $2.8 \pm 1.0$ & $\ldots$ \\
\hline 10 & $6.0 \pm 1.9$ & $1.4 \pm 0.3$ & $\ldots$ & $5.7 \pm 1.3$ & $4.5 \pm 1.6$ & $\ldots$ \\
\hline 11 & $4.3 \pm 1.3$ & $1.6 \pm 0.5$ & $\ldots$ & $0.9 \pm 0.4$ & $11.3 \pm 2.1$ & $\ldots$ \\
\hline 12 & $3.0 \pm 1.2$ & $0.8 \pm 0.3$ & $\ldots$ & $5.4 \pm 1.3$ & $5.0 \pm 0.9$ & $\ldots$ \\
\hline 13 & $3.6 \pm 1.3$ & $0.7 \pm 0.2$ & $\ldots$ & $3.8 \pm 1.3$ & $4.0 \pm 1.8$ & $\ldots$ \\
\hline 16 & $3.6 \pm 1.1$ & $1.8 \pm 0.6$ & $\ldots$ & $8.2 \pm 1.7$ & $16.5 \pm 2.0$ & $\ldots$ \\
\hline
\end{tabular}

a Values are mean \pm standard error of the mean of $10(1996,1997)$ or $20(1998)$ boxes of fruit.

Table 6. Linear correlations between populations of Botrytis cinerea and Penicillium spp. on the surface of 'd'Anjou' pear fruit, in orchard and packinghouse air and orchard soil and litter, to incidence of postharvest decay caused by these pathogens in storage

\begin{tabular}{|c|c|c|c|c|c|}
\hline Pathogen & Comparison & Year & $n^{\mathrm{a}}$ & Correlation coefficient & $P$ value \\
\hline Botrytis & Surface versus litter & 1996 & 12 & 0.191 & 0.55 \\
\hline Botrytis & Surface versus litter & 1997 & 13 & 0.216 & 0.48 \\
\hline Botrytis & Surface versus litter & 1998 & 7 & 0.418 & 0.35 \\
\hline Botrytis & Surface versus air & 1996 & 16 & 0.048 & 0.86 \\
\hline Botrytis & Surface versus air & 1997 & 13 & 0.131 & 0.67 \\
\hline Botrytis & Surface versus air & 1998 & 6 & 0.761 & 0.08 \\
\hline Botrytis & Litter versus air & 1996 & 12 & 0.467 & 0.13 \\
\hline Botrytis & Litter versus air & 1997 & 13 & 0.264 & 0.38 \\
\hline Botrytis & Litter versus air & 1998 & 6 & 0.733 & 0.10 \\
\hline Botrytis & Decay versus air & 1996 & 14 & 0.048 & 0.87 \\
\hline Botrytis & Decay versus air & 1997 & 13 & 0.311 & 0.30 \\
\hline Botrytis & Decay versus air & 1998 & 6 & 0.377 & 0.46 \\
\hline Botrytis & Decay versus litter & 1996 & 12 & 0.062 & 0.85 \\
\hline Botrytis & Decay versus litter & 1997 & 13 & 0.474 & 0.10 \\
\hline Botrytis & Decay versus litter & 1998 & 6 & 0.795 & 0.89 \\
\hline Botrytis & Decay versus surface & 1996 & 14 & 0.584 & 0.03 \\
\hline Botrytis & Decay versus surface & 1997 & 13 & 0.162 & 0.60 \\
\hline Botrytis & Decay versus surface & 1998 & 6 & 0.795 & 0.05 \\
\hline Penicillium & Surface versus soil & 1998 & 7 & 0.312 & 0.50 \\
\hline Penicillium & Surface versus litter & 1998 & 7 & 0.606 & 0.15 \\
\hline Penicillium & Surface versus air & 1998 & 6 & 0.22 & 0.67 \\
\hline Penicillium & Soil versus air & 1998 & 6 & 0.15 & 0.78 \\
\hline Penicillium & Litter versus air & 1998 & 6 & 0.445 & 0.38 \\
\hline Penicillium & Soil versus litter & 1998 & 7 & 0.356 & 0.43 \\
\hline Penicillium & Decay versus air & 1996 & 14 & 0.218 & 0.45 \\
\hline Penicillium & Decay versus air & 1998 & 6 & 0.185 & 0.73 \\
\hline Penicillium & Decay versus soil & 1998 & 6 & 0.255 & 0.63 \\
\hline Penicillium & Decay versus litter & 1998 & 6 & 0.568 & 0.24 \\
\hline Penicillium & Decay versus surface & 1998 & 6 & 0.904 & 0.01 \\
\hline
\end{tabular}

${ }^{a}$ Number of data pairs used to calculate each correlation coefficient.

fruit. Spotts and Cervantes (23) showed that low inoculum concentrations $(<10$ $\mathrm{CFU} / \mathrm{cm}^{2}$ ) of both $B$. cinerea and $P$. expansum on fruit surfaces can cause significant levels of decay in storage if the fruit is wounded. Injuries to pear fruit sustained during harvest and transit to packinghouses and handling in the packinghouse provide both these pathogens with ideal infection courts. The incorporation of fruit surface inoculum levels recorded in this study into regression equations obtained by Spotts and Cervantes (23) indicates that the inoculum levels should cause commercially unacceptable levels of gray and blue mold.

For inoculum deposited on the pear fruit surface to be effective, it must survive this relatively harsh environment. Spotts (20) found that $50 \%$ of conidia of $B$. cinerea survived for approximately 14 days in the orchard, whereas $50 \%$ of $P$. expansum conidia died after approximately 6 days. Consequently, conidia of these species landing on the pear surface earlier than 2 weeks before harvest are unlikely to contribute to decay unless they form latent infections. Direct penetration of a number of hosts by conidial germ tubes of $B$. cinerea has been described (26), and Rijkenberg et al. (16) found morphological evidence of latent infection of $B$. cinerea in tomato fruit. However, whether latent infections play a significant role in the epidemiology of $B$. cinerea and $P$. expansum on pear fruit seems unlikely in light of the results of Spotts (19), who found that both of these pathogens require a wound for infection.

Inoculum levels of $B$. cinerea have been measured in the air in strawberry and raspberry fields $(9,14)$, with dispersal being related to weather. Propagule density in the air of d'Anjou pear orchards prior to commercial harvest ranged from nondetectable to $3.1 \mathrm{CFU} /$ liter for $B$. cinerea, and from nondetectable to $3.13 \mathrm{CFU} /$ liter for Penicillium spp. The regression equations of Spotts and Cervantes (23) show that densities of $B$. cinerea and $P$. expansum in air of less than 3 conidia/liter can cause significant levels of decay in storage. Consequently, inoculum levels detected in this study were sufficient to cause postharvest decay.

Population densities of Penicillium spp. in air collected near operating packinglines of commercial packinghouses ranged from 0.1 to $11.8 \mathrm{CFU} /$ liter and samples collected after January each year showed higher levels of this pathogen. Spotts and Cervantes (21) noticed a similar increase in Penicillium spp. in both packinghouse air and dump water as the packing season progressed. They attributed this increase in population density to decaying fruit stored in bins that are passed through the dump tank water during packing operations. Air samples collected from the cold-storage facilities had lower levels of Penicillium 
spp. (ranging from nondetectable to 3.9 CFU/liter) than packingline air samples, and the population density increases of this pathogen observed in packingline air samples were not observed. These levels reflect the relatively undisturbed environment of the cold-storage facilities. Once the fruit is taken out of cold storage and processed for packing, Penicillium spp. inoculum probably is dispersed into the air or dump tank water.

Inoculum of $B$. cinerea seldom was found in soil samples collected in commercial d'Anjou pear orchards before harvest although, in some orchards, inoculum levels ranging from 26 to $125 \mathrm{CFU} / \mathrm{g}$ of soil were detected. These results corroborate those of Barron (2), who infrequently detected Botrytis spp. in the soil. B. cinerea is known to have a poor competitive ability in the soil (7) and a low sporulation capacity in the dark $(2,10)$; therefore, populations of $B$. cinerea in the soil are likely to remain low. Significant population densities of $B$. cinerea were detected in litter samples collected in some commercial d'Anjou pear orchards before harvest, with levels ranging from 0 to $1,167 \mathrm{CFU} / \mathrm{g}$. Litter provides an ideal medium for saprophytic growth of $B$. cinerea and $P$. expansum (25).

Populations of Penicillium spp. in soil were consistently lower than those in litter. Penicillium spp. are aggressive colonizers of both soil and plant litter $(8,25)$. Their battery of enzymes and production of antimicrobial compounds (25) give them a competitive edge over other organisms (including $B$. cinerea) in both substrates. Based on the results of this study, contamination of bins with soil and litter could introduce inoculum of both $B$. cinerea and, to a greater extent, Penicillium spp. into the packinghouse environment, particularly into dump tank water $(18,21,22)$.

Incidence of gray mold caused by $B$. cinerea and blue mold caused by $P$. expansum in stored d'Anjou pear fruit from several commercial orchards varied considerably over the 3 years in which fruit was stored and evaluated for decay. Currently, the pear fruit industry must maintain decay incidence at less than $2 \%$ to avoid marketing problems, and decay incidence in fruit from several of the orchards often exceeded this amount during this study.

Of all relationships between population levels of both $B$. cinerea and Penicillium spp. and between population levels and decay in storage, only population levels on fruit surfaces were significantly and positively correlated to decay in storage. It would appear that inoculum levels of $B$. cinerea and Penicillium spp. in orchard and packinghouse air and orchard soil and litter cannot be used as indicators of postharvest decay, whereas inoculum levels on fruit surfaces may prove to be useful predictors of decay. This does not imply that inoculum in the orchard and packinghouse air and orchard soil and litter does not contribute to the epidemiology of these two pathogens in causing postharvest decay in pears. It can reasonably be assumed that inoculum produced on soil, litter, and plant material in the orchard, as detected in the orchard air, would be largely responsible for initial inoculum levels detected on fruit surfaces as they leave the orchard and enter the packinghouse environment. Our study, combined with those of Sanderson and Spotts (18) and Spotts and Cervantes (21), show that the build-up of Penicillium spp. inoculum in fruit stored in bins and packed late in the season is a real threat to the Pacific Northwest pear industry because considerable numbers of conidia are dispersed in dump tank water and contaminate clean fruit.

The results of this study indicate the importance of reducing the inoculum levels of these two pathogens. Current orchard management practices aimed at reducing the amount of initial inoculum involve sanitation methods such as regular mowing of grass or cover crops, removal of fallen fruit, clean bins, and a preharvest application of a contact or protectant fungicide to reduce the number of viable propagules contaminating fruit surfaces. Over-mature fruit is more susceptible to both $B$. cinerea and $P$. expansum (19); therefore, fruit should be harvested at the optimal stage of maturity to avoid infection. During harvest, fruit is handled and transported carefully to minimize wounding. Although wounds sustained by pear fruit undergo a healing process with time (24), wounded fruit are far more susceptible to decay than nonwounded fruit (21).

The controlled environment of the packinghouse provides an opportunity for the control of decay fungi through the use of sanitation and fungicides. Chlorine or sodium o-phenylphenate are used to sanitize the water in flumes (4), and captan or thiabendazole is applied as a drench or line spray in many packinghouses $(1,12)$. Thiabendazole is effective against both $B$. cinerea and $P$. expansum (3), although resistant isolates have been detected in populations of both fungi in the Pacific Northwest $(3,21)$. Due to residue limitations on fruit for the export market, captan is seldom used in the industry.

In conclusion, inoculum levels of these important postharvest pathogens in orchard and packinghouse air and in orchard soil and litter are not reliable as indicators of postharvest decay, whereas inoculum levels on fruit surfaces may be useful predictors of decay. Reducing inoculum levels before fruit enters the packinghouse remains the best line of defense against decay caused by $B$. cinerea and Penicillium spp.

\section{ACKNOWLEDGMENTS}

We thank the Winter Pear Control Committee for partial funding of the research.
LITERATURE CITED

1. Anon. 1992. Management practices to minimize postharvest decay of apples and pears. Tree Fruit Postharvest J. 3:5-8.

2. Barron, G. L. 1968. The Genera of Hyphomycetes from Soil. Williams and Wilkins, Baltimore.

3. Bertrand, P. F., and Saulie-Carter, J. L. 1978. The occurrence of benomyl-tolerant strains of Penicillium expansum and Botrytis cinerea in the Mid-Columbia region of Oregon and Washington. Plant Dis. Rep. 62:302-305.

4. Bertrand, P. F., and Saulie-Carter, J. L. 1979. Postharvest decay control of apples and pears after immersion dumping. Ore. State Univ. Exp. Stn. Spec. Rep. 545.

5. Blanpied, G. D., and Purnasiri, A. 1968. Penicillium and Botrytis rot of McIntosh apples handled in water. Plant Dis. Rep. 52:865-867.

6. Chen, P. M., Varga, D. M., Mielke, E. A., Facteau, T. J., and Drake, S. R. 1990. Control of superficial scald on 'd'Anjou' pears by ethoxyquin: oxidation of $\alpha$-farnesene and its inhibition. J. Food Sci. 55:171-175, 180.

7. Coley-Smith, J. R. 1979. Survival of plant pathogenic fungi in soil in the absence of host plants. Pages 39-57 in: Soil-Borne Plant Pathogens. B. Schippers and W. Gams, eds. Academic Press, London.

8. Domsch, K. H., Gams, W., and Anderson, T. H. 1980. Compendium of Soil Fungi, Vol. 1. Academic Press, London.

9. Jarvis, W. R. 1962. The dispersal of spores of Botrytis cinerea in a raspberry plantation. Trans. Br. Mycol. Soc. 45:549-559.

10. Jarvis, W. R. 1977. Botryotina and Botrytis species: Taxonomy, Physiology, and Pathogenicity. Can. Dep. Agric. Monogr. No. 15.

11. Kerssies, A. 1990. A selective medium for Botrytis cinerea to be used in a spore-trap. Neth. J. Plant Pathol. 96:247-250.

12. Kupferman, E. 1998. Postharvest applied chemicals to pears: a survey of pear packers in Washington, Oregon, and California. Tree Fruit Postharvest J. 9:3-24.

13. Lennox, C. L., and Spotts, R. A. 1997. Botrytis gray mold as a postharvest pathogen in 'd'Anjou' pear. Pages 93-95 in: Proc. 13th Annu. Washington Tree Fruit Postharvest Conf. E. Kupferman, ed. Washington State Horticultural Association, Wenatchee.

14. Miller, P. M., and Waggoner, P. E. 1957. Dispersal of spores of Botrytis cinerea among strawberries. (Abstr.) Phytopathology 47:24.

15. Pierson, D. F., Ceponis, M. J., and McColloch, L. P. 1971. Market diseases of apples, pears, and quinces. U. S. Dep. Agric. Agric. Handb. 376, Washington, DC.

16. Rijkenberg, F. H. J., De Leeuw, G. T. N., and Verhoeff, K. 1980. Light and electron microscopy studies on the infection of tomato fruits by Botrytis cinerea. Can. J. Bot. 58:13941404.

17. Salinas, J., Glandorf, D. C. M., Picavet, F. D., and Verhoeff, K. 1989. Effects of temperature, relative humidity and age of conidia on the incidence of spotting on gerbera flowers caused by Botrytis cinerea. Neth. J. Plant Pathol. 95:51-64.

18. Sanderson, P. G., and Spotts, R. A. 1995. Postharvest decay of winter pear and apple fruit caused by species of Penicillium. Phytopathology 85:103-110.

19. Spotts, R. A. 1985. Effect of preharvest pear fruit maturity on decay resistance. Plant Dis. 69:388-390.

20. Spotts, R. A. 1985. Environmental factors affecting conidial survival of five pear decay fungi. Plant Dis. 69:391-392.

21. Spotts, R. A., and Cervantes, L. A. 1986. Populations, pathogenicity, and benomyl resistance of Botrytis spp., Penicillium spp., 
and Mucor piriformis in packinghouses. Plant Dis. 70:106-108

22. Spotts, R. A., and Cervantes, L. A. 1994. Contamination of harvest bins with pear decay fungi and evaluation of disinfectants on plastic and wood bin material. Acta Hortic. 367:419-425.

23. Spotts, R. A., and Cervantes, L. A. 2001.
Disease incidence-inoculum dose relationships for Botrytis cinerea and Penicillium expansum and decay of pear fruit using dry, airborne conidia. Plant Dis. 85:755-759.

24. Spotts, R. A., Sanderson, P. G., Lennox, C. L., and Cervantes, L. A. 1998. Wounding, wound healing and staining of mature pear fruit. Postharvest Biol. Technol. 13:27-36.
25. Subramanian, C. V. 1983. Hyphomycetes Taxonomy and Biology. Academic Press, London.

26. Verhoeff, K. 1980. The infection process and host-pathogen interactions. Pages 153-180 in: The Biology of Botrytis. J. R. Coley-Smith,

K. Verhoeff, and W. R. Jarvis, eds. Academic Press, London. 